\title{
Specifics of Sex Life and Methods of Birth Control Among Students at the University of Osijek
}

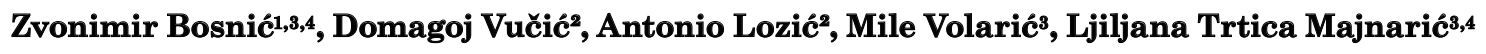 \\ ${ }^{1}$ Health Centre Slavonski Brod, Slavonski Brod, Croatia \\ ${ }^{2}$ General Hospital Dr Josip Bencevic Slavonski Brod, Slavonski Brod, Croatia \\ ${ }^{3}$ Department of Internal Medicine, Family Medicine and the History of Medicine, Faculty of Josip Juraj Strossmayer University of \\ Osijek, Osijek, Croatia \\ ${ }^{4}$ Department of Public Health, Faculty of Dental Medicine and Health, Josip Juraj Strossmayer University of Osijek, Osijek, Croatia
}

\begin{abstract}
A B S T R A C T
The aim of this study is to define specifics of sex life and methods of birth control among students at the University of Osijek. Participants were students who study at Josip Juraj Strossmayer University of Osijek. A newly formed questionnaire containing 31 questions was used for this purpose. The study included 549 voluntarily students, 54.3\% of students had first sexual experience between 16 and 18 years of age. Most of them were long-term couples, who are managing better with sexual activities then students in short-term relationships, who are more stressed because of their studies. When it comes to the type of contraceptives, 71, $9 \%$ of students used some of birth control methods, and most common is condom (75.9\%). However, 27. $9 \%$ of students believe that natural methods of birth are safe enough. There are no significant differences in age at the time of first sexual activity considering gender, year at university and residency. The biggest reason for not using contraception is long-term relationship in which students do not feel fear of sexually transmitted diseases and pregnancy.
\end{abstract}

Key words: contraception, students, condoms, education, teen pregnancies

\section{Introduction}

Responsible sexual behavior and maintaining personal hygiene are important characteristics of sexual health. This behavior includes preventive medical examination, the use of condoms and/or other contraceptives ${ }^{1}$. Early sexual activity can enhance the risk of unplanned pregnancy and/or sexually transmitted diseases, mostly due to an incorrect use of a condom or other contraceptives, and the risk of unpleasant emotions because of the emotional immaturity of the person ${ }^{2}$. Unwanted teen pregnancy is a great social and public health problem in America where over a million adolescents fall pregnant ${ }^{3}$. A repercussion of sexual activity are sexually transmitted diseases whose treatment is far more successful than it was in previous years. Nevertheless, the success of the treatment depends on how soon did the infected person ask for medical help and how disciplined this person was during the treatment. The choice of contraceptives depends on different factors like age, plans for the future, marital status, sexual attitudes, financial status, religious believes, health and previous experiences ${ }^{4,5}$. There is no such thing as an ideal contraceptive. Therefore, when choosing a contraceptive, one must choose, in agreement with the partner, which of the contraceptives suits them best. A particular contraceptive is not necessarily convenient for everybody. Reasons for that are several: different health status, sexual activity frequency, different fertility levels, etc. ${ }^{1,5}$. The main reason for using contraceptives is to prevent unwanted pregnancy. Such pregnancies often occur with adolescents. There are different contraceptives these days like condoms, oral contraceptives, intrauterine contraceptive device and postcoital contraceptive methods ${ }^{6,7}$. The objective of this study is to define specific characteristics of the sexual activity and use of contraceptives among students at the University in Osijek. It is conducted by a newly formed questionnaire whose aim is to investigate which contraceptives our students use and to obtain an insight into the particularities of the sexual behavior the students manifest. Furthermore, gender differences, age, relationship status (long-term or temporary) and residency (village or city) will be differentiated in the data analysis.

Received for publication March 12. 2021 


\section{Materials and methods}

\section{Study design}

This is a cross-sectional study ${ }^{8}$. It was performed at the Department of Internal Medicine, Family Medicine and the History of Medicine at the Faculty of Medicine, Josip Juraj Strossmayer University of Osijek, with the permission of the Ethics Committee at the University.

\section{Study population}

Participants in this study were students of different age and gender at the University in Osijek. Several faculties were included in the study due to significant differences in gender distribution among the faculties: Faculty of Electrical Engineering, Computer Science and Information Technology, and Faculty of Teacher Education. The study included 549 participants; 268 participants were in their first and second year, and 281 participants were in their final years of university education (third, fourth, fifth and postgraduates). In terms of gender, there were 128 male and 421 female participants.

\section{Study variables}

An anonymous self-administered 31-item questionnaire designed by researchers was used to define specific characteristics of the sexual activity and use of contraceptives among students at the University in Osijek.

The first draft of the questionnaire was conducted as a pilot study on 200 participants at the University in Osijek, and reviewed by a panel of professionals, which consisted of three professors at the Medical Faculty of Osijek, with experience in survey-type research. In concordance with the reliability analysis and the validity of questionnaire (Cronbach's alpha $>0.80$ ), the study was conducted with no additional corrections in a larger sample (total number of 549 participants).

Some of the questions are multiple-choice questions with only one possible answer. Other questions are based on the Likert scale. The first part of the questionnaire contains demographic and personal information, while the second part refers to the particularities of the participants' sexual behavior and the use of contraceptives.

\section{Statistical analysis}

Categorical data are presented by absolute and relative frequencies. Differences between categorical variables were tested by the chi-squared test, and, when necessary, by Fisher's exact test. Normality distribution of the numeric variables was tested by the Shapiro-Wilk test. The differences between the numeric variables were tested by the Mann-Whitney U test due to a deviation from normal distribution. Every $\mathrm{P}$ value is two-sided. The level of significance is set to $X^{2}=0,05$ (9). Statistical analysis was performed by MedCalc statistical software (version 16.2.0, MedCalc Software bvba, Ostend, Belgium).

\section{Results}

This study included 549 participants consisting of 128 (23.3\%) males and 421 (76.7\%) females. Most of the participants. 101 (18.4\%) were 21 years old and only 7 students were aged 18. As to the university level. 146 (26.6\%) participants were attending their first year. Also, 231 (38.8\%) participants came from a town (Slavonski Brod, Vinkovci, Vukovar, Požega), whereas 139 (25.3\%) come from a city (Zagreb, Rijeka, Split or Osijek). When it comes to relationships, $384(69.9 \%)$ participants were in a long-term relationship, 11 (2\%) participants were married and 18 (3.3\%) participants still had not experienced any type of relationship ( Table 1). First sexual activity before age 16 was reported in 64 cases (12. $2 \%$ ), between ages 16 and 18 in $284(54.3 \%)$ cases, at the age of 19 in $138(26.4 \%)$ cases, while in $37(7.1 \%)$ cases participants never had a sexual intercourse. There were no significant differences in results by gender, year at the university or residency (Table 2). In relation to specific characteristics of their sexual activity, 380 (69.6\%) participants stated that they enjoyed it. On the other hand, 32 (5.8\%) participants stated that they had problems in fulfilling their sexual needs and would like to receive professional help. Furthermore, 56 (10.2\%) participants stated that they

TABLE 1

DEMOGRAPHIC DATA

\begin{tabular}{|c|c|}
\hline & $\mathrm{N}(\%)$ \\
\hline \multicolumn{2}{|l|}{ Gender } \\
\hline male & $128(23.3)$ \\
\hline female & $421(76.7)$ \\
\hline \multicolumn{2}{|l|}{ Year at university } \\
\hline 1 & $146(26.6)$ \\
\hline 2 & $122(22.2)$ \\
\hline 3 & $102(18.6)$ \\
\hline 4 & $78(14.2)$ \\
\hline 5 & $80(14.6)$ \\
\hline postgraduate & $21(3.8)$ \\
\hline \multicolumn{2}{|l|}{ Residency } \\
\hline city (Zagreb, Rijeka , Split, Osijek) & $139(25.3)$ \\
\hline $\begin{array}{l}\text { town (Slavonski Brod, Vinkovci, Vukovar, } \\
\text { Požega) }\end{array}$ & $213(38.8)$ \\
\hline village & $177(32.2)$ \\
\hline $\begin{array}{l}\text { Bosnia and Herzegovina or other neighboring } \\
\text { countries }\end{array}$ & $16(2.9)$ \\
\hline other countries & $4(0.7)$ \\
\hline \multicolumn{2}{|l|}{ Current relationship status } \\
\hline long term relationship & $384(69.9)$ \\
\hline married & $11(2)$ \\
\hline single, but I had relationships in the past & $99(18)$ \\
\hline $\begin{array}{l}\text { I find partners for occasional intercourse, I do } \\
\text { not want a serious relationship }\end{array}$ & $37(6.7)$ \\
\hline I have not had any type of relationship & $18(3.3)$ \\
\hline
\end{tabular}


TABLE 2

FIRST SEXUAL ACTIVITY BY AGE, YEAR AT THE UNIVERSITY AND RESIDENCY

\begin{tabular}{|c|c|c|c|c|c|c|}
\hline \multirow[b]{2}{*}{ age at the time of first intercourse } & \multicolumn{5}{|c|}{$\mathrm{N}(\%)$} & \multirow{2}{*}{$\mathrm{P}^{*}$} \\
\hline & $\begin{array}{l}\text { before the age } \\
\text { of } 16\end{array}$ & $\begin{array}{l}\text { between } 16 \\
\text { and18 years }\end{array}$ & $\begin{array}{l}\text { at the age of } 19 \\
\text { and above }\end{array}$ & $\begin{array}{l}\text { have not had } \\
\text { intercourse }\end{array}$ & total & \\
\hline \multicolumn{7}{|l|}{ gender } \\
\hline male & $15(23)$ & $59(20)$ & $44(30)$ & $8(20)$ & $126(23.2)$ & 0.13 \\
\hline female & $50(77)$ & $233(80)$ & $102(70)$ & $32(80)$ & $417(76.8)$ & \\
\hline \multicolumn{7}{|l|}{ year at the university } \\
\hline first two years & $42(65)$ & $204(70)$ & $90(62)$ & $28(70)$ & $364(67)$ & 0.35 \\
\hline last three years and postgraduate & $23(35)$ & $88(30)$ & $56(38)$ & $12(30)$ & $179(33)$ & \\
\hline \multicolumn{7}{|l|}{ †residency } \\
\hline city/town & $47(73)$ & $196(69)$ & $82(59)$ & $21(57)$ & $346(66.2)$ & 0.08 \\
\hline village & $17(27)$ & $88(31)$ & $56(41)$ & $16(43)$ & $177(33.8)$ & \\
\hline total & $64(100)$ & $284(100)$ & $138(100)$ & $37(100)$ & $523(100)$ & \\
\hline
\end{tabular}

†only in Croatia

had delayed their sexual activity due to stress caused by studying. As to sexual needs, 81 (14.8\%) participants stated that they did not feel any particular need for sex. Those participants who were in a long-term relationship reported positive experiences with respect to all aspects of sexual activity. On the other hand, participants who were involved in short-term relationships showed signs of significant stress caused by studying ( $\mathrm{X}^{2}$ test, $\left.\mathrm{P}<0.001\right)$ (Table 3). When it comes to contraceptives, a significant number of the participants used some kind of protection despite the fact that they were in a long-term relationship. Furthermore, there was no significant difference by the place of residence in the application of natural contraceptive methods (coitus interruptus, avoiding fertile days, and abstention as the safest method, which is why many of them did not have a partner) (Fisher's exact test, $\mathrm{P}=0.004$ ) (Table 4). Furthermore, 395 (71.9\%) participants used some kind of contraceptive. The most common contraceptive was a condom (75.9\%). Other contraceptives were pills $(23.3 \%)$, intrauterine device or a combination

TABLE 3

SPECIFIC CHARACTERISTICS OF SEXUAL ACTIVITY N (\%)

\begin{tabular}{|c|c|c|c|c|c|c|}
\hline Sexual activity & $\begin{array}{l}\text { I manage it well } \\
\text { it gives me great } \\
\text { pleasure. }\end{array}$ & $\begin{array}{l}\text { I have problems with fulfilling } \\
\text { my sexual needs and could use } \\
\text { professional help and guidance. }\end{array}$ & $\begin{array}{l}\text { I have delayed sexual } \\
\text { activity due to my } \\
\text { stressful obligations. }\end{array}$ & $\begin{array}{l}\text { I usually do not } \\
\text { have strong } \\
\text { sexual needs. }\end{array}$ & Total & $\mathrm{P}$ \\
\hline \multicolumn{7}{|l|}{ Gender } \\
\hline male & $99(26)$ & $7(22)$ & $12(21)$ & $10(12)$ & $128(23.3)$ & 0.06 \\
\hline female & $281(74)$ & $25(78)$ & $44(79)$ & $71(88)$ & $421(76.7)$ & \\
\hline total & $380(100)$ & $32(100)$ & $56(100)$ & $81(100)$ & $549(100)$ & \\
\hline \multicolumn{7}{|c|}{ Year at university } \\
\hline first two years & $250(66)$ & $27(84)$ & $41(73)$ & $52(64)$ & $370(67.4)$ & 0.11 \\
\hline final years & $130(34)$ & $5(16)$ & $15(27)$ & $29(36)$ & $179(32.6)$ & \\
\hline total & $380(100)$ & $32(100)$ & $56(100)$ & $81(100)$ & $549(100)$ & \\
\hline \multicolumn{7}{|l|}{$\dagger$ Residency } \\
\hline city/town & $250(68)$ & $18(64)$ & $29(54)$ & $55(71)$ & $352(66.5)$ & 0.19 \\
\hline village & $119(32)$ & $10(36)$ & $25(46)$ & $23(29)$ & 177 (33.5) & \\
\hline total & $369(100)$ & $28(100)$ & $54(100)$ & $78(100)$ & $529(100)$ & \\
\hline \multicolumn{7}{|c|}{ Relationship status } \\
\hline long-term & $314(83)$ & $21(66)$ & $14(25)$ & $46(57)$ & 395 (71.9) & $<0.001$ \\
\hline short-term & $66(17)$ & $11(34)$ & $42(75)$ & $35(43)$ & $154(28.1)$ & \\
\hline total & $380(100)$ & $32(100)$ & $56(100)$ & $81(100)$ & $549(100)$ & \\
\hline
\end{tabular}

* $\mathrm{X}^{2}$ test; †only in Croatia 
TABLE 4

USE OF CONTRACEPTIVES BY RESIDENCY

\begin{tabular}{|c|c|c|c|c|}
\hline & \multicolumn{3}{|c|}{$\mathrm{N}(\%)$} & \multirow[t]{2}{*}{$\mathrm{P}^{*}$} \\
\hline & city/town & village & total & \\
\hline I am in a long-term relationship and I do not use any type of contraceptives & $46(13)$ & $11(6)$ & $57(11)$ & 0.004 \\
\hline I have occasional relationships, but I do not use any type of contraceptives & $6(2)$ & $5(3)$ & $11(2)$ & \\
\hline I apply only natural methods like coitus interruptus or avoiding fertile days & $68(19)$ & $35(20)$ & $103(19)$ & \\
\hline I use contraceptives even though I am in a long-term relationship & $200(57)$ & $91(51)$ & $291(55)$ & \\
\hline $\begin{array}{l}\text { I sometimes use contraceptive (when my partner has some sexually transmitted } \\
\text { disease or for unplanned intercourse) }\end{array}$ & $15(4)$ & $16(9)$ & $31(6)$ & \\
\hline I practice abstention which is why I do not have a partner & $17(5)$ & $19(11)$ & $36(7)$ & \\
\hline Total & $352(100)$ & $177(100)$ & $529(100)$ & \\
\hline
\end{tabular}

*Fisher's exact test

of methods (condoms, diaphragms, spermicide, and intrauterine device). In terms of the availability of contraceptives, most of the participants, 270 (49.2\%). stated that they were available. However, 69 (12.6\%) participants stated that contraceptives were not available because not everybody was informed enough on how to use them, and $67(12.2 \%)$ participants stated that contraceptives were not available because they were too expensive. Finally, 58 (10.6\%) participants did not have opinion on the availability of contraceptives (Figure 1). Participants who did not use any type of contraceptives had a permanent partner and therefore had no fear of sexually transmitted diseases or pregnancy. When it comes to natural methods of birth control, 43 (27.9\%) participants stated these methods were enough. Uncomfortable feelings when talking to their partners about contraceptives were not important to $145(94.2 \%)$ participants. The lack of knowledge on contraceptives was not important for 131 (85. 1\%) participants, while for 128 (83.1\%) participants religious reasons were of least importance (Table 5). As there is cur- rently no official service in Croatia where adolescents could find information and help regarding their sexual health, 377 (68.7\%) participants said they would get advice from gynecologists, 30 (5.5\%) from friends, 24 (4.4\%) through health education in school, while 45 (8.2\%) stated that they did not know who to turn to (Figure 2).

\section{Discussion and Conclusion}

The statistical data analysis and comparison of the results showed both similarities and differences between the observed characteristics of the participants. Young adulthood still presents a critical period in human life when a variety of mental disorders and unfavorable behaviors tend to get their roots ${ }^{10}$. The majority of the participants in the study were 21 years old and at their first year at the university, they came from towns or cities and were involved in a serious long-term relationship (Table 1). The majority of the participants experienced their first

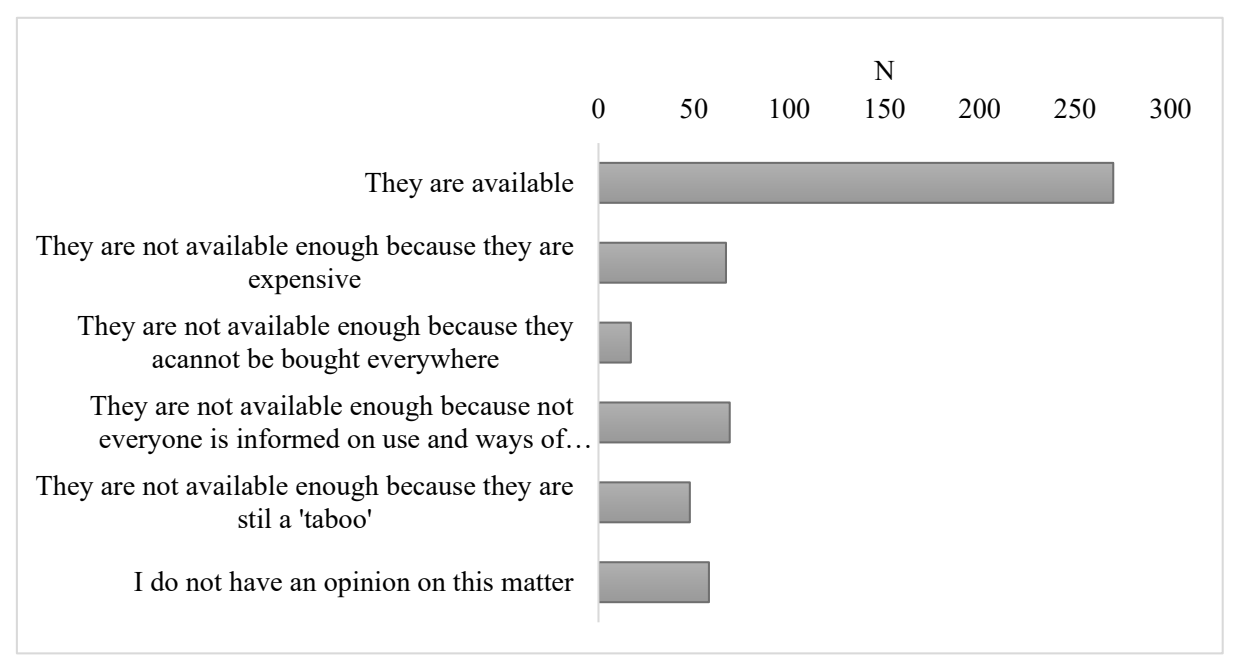

Fig 1. Availability of contraceptives. 
TABLE 5

CRITERIA FOR CHOOSING CONTRACEPTIVES

\begin{tabular}{|c|c|c|c|c|}
\hline & \multicolumn{4}{|c|}{$\mathrm{N}(\%)$} \\
\hline & least important & important & most important & total \\
\hline I am not informed enough & $131(85.1)$ & $15(9.7)$ & $8(5.2)$ & $154(100)$ \\
\hline $\begin{array}{l}\text { I have a long-term serious partner and I am not afraid of diseases or } \\
\text { pregnancy }\end{array}$ & $30(19.5)$ & $47(30.5)$ & $77(50)$ & $154(100)$ \\
\hline I am uncomfortable to talk about it with my partner & $145(94.2)$ & $5(3.2)$ & $4(2.6)$ & $154(100)$ \\
\hline $\begin{array}{l}\text { My partner does not want to use contraceptives and I accept their } \\
\text { choice }\end{array}$ & $126(81.8)$ & $19(12.3)$ & $9(5.8)$ & $154(100)$ \\
\hline I am afraid contraceptive pills damage health & $55(35.7)$ & $58(37.7)$ & $41(26.6)$ & $154(100)$ \\
\hline Mechanical methods disable spontaneity & $74(48.1)$ & $54(35.1)$ & $26(16.9)$ & $154(100)$ \\
\hline My religion does not allow contraceptives & $128(83.1)$ & $11(7.1)$ & $15(9.7)$ & $154(100)$ \\
\hline Natural methods of birth control are enough & $61(39.6)$ & $50(32.5)$ & $43(27.9)$ & $154(100)$ \\
\hline I feel embarrassed when buying contraceptives & $129(83.8)$ & $19(12.3)$ & $6(3.9)$ & $154(100)$ \\
\hline
\end{tabular}

intercourse between 16 and 18 years of age which is related to the first steady long-term relationships, going clubbing, gradually gaining independence and getting to know their own sexuality (Table 2). It is important to point out that there were no significant differences in the beginnings of sexual activity by gender, year at university or residency. Human sexual activities have changed in the past decade under media influence, particularly among young females. They have also been affected by increased alcohol consumption, as well as the availability of different opiates, which can be related to a greater number of different sexual partners ${ }^{11}$. The majority of the participants, had, in average, between two and five sexual partners (Table 2). This can be interpreted as a significant expression of one's own sexuality particularly among women who became much more adventurous; women have twice as many sexual partners than they had 20 years ago. Furthermore, a study conducted in Iran shows that $8 \%$ of the women in that country have had sexual relations before marriage ${ }^{12}$. Today, an average woman has eight partners

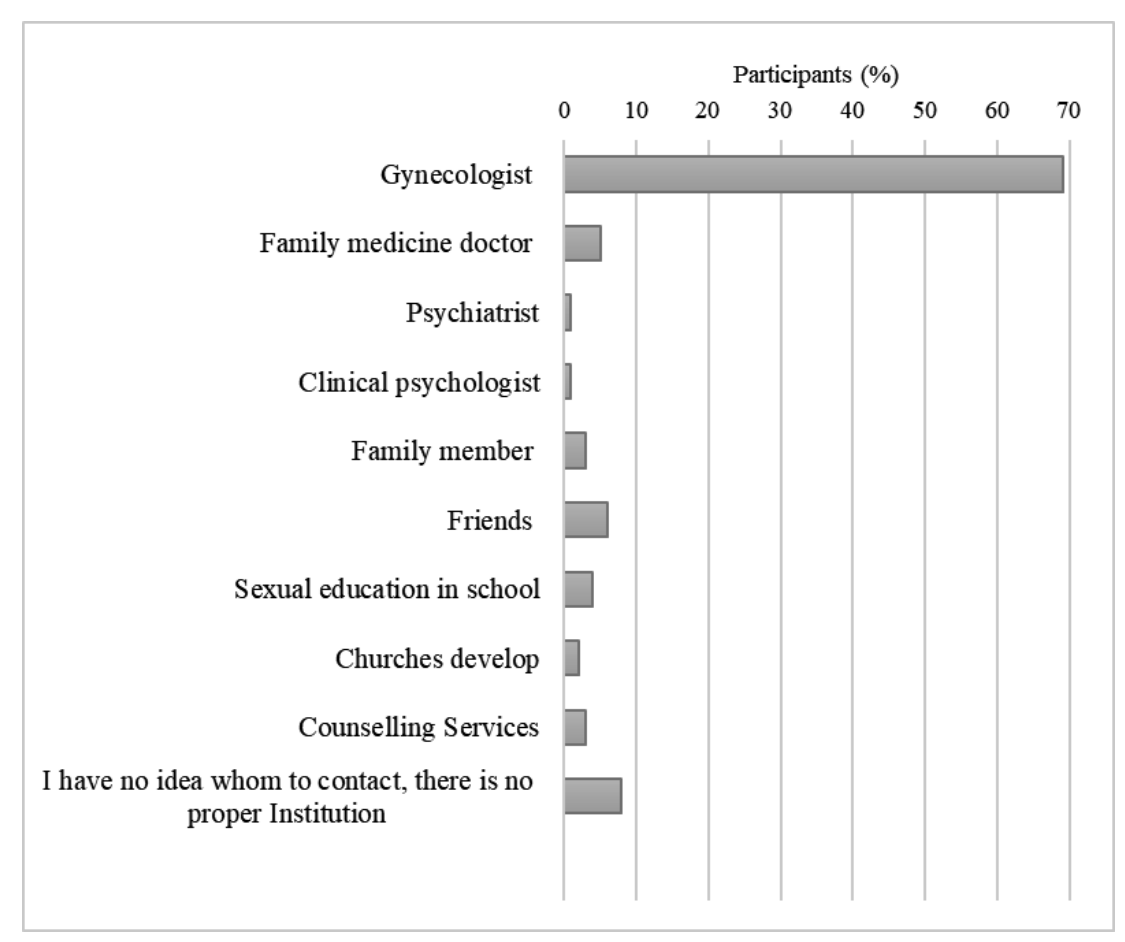

Fig 2. Distribution of participants according to information and help regarding their sexual health. 
and a man has around 12 partners. In addition, average age of female adolescents when they start their sexual activity has significantly decreased in the last three decades $^{13}$. As it is well known ever since the ancient times, sexuality mesmerizes people of all professions ${ }^{1}$. This study confirms this statement considering that 197 (35. 9\%) participants acknowledge the importance of sexuality in their lives (Table 3). These participants were mostly students in steady long-term relationships at their first year of study. A smaller number of participants exhibit less interest in sexual relations because of the stress they experience during university education (Table 3). It has been proven that greater amount of stress leads to disturbed sleeping and eating regime and thus affects one's health as well as sexual health ${ }^{14}$. Participants who are in a longterm relationship are significantly more at ease when it comes to sexual activity. This is because in long-term relationships, partners get to know each other very well and have an open and honest communication with each other. It is also possible to say that students who experience a lot of stress because of their studies find themselves inclined to short-term relationships.

Unlike in the beginning of the 1970', when male adolescents started their sexual activity earlier than their female peers, today the situation is similar in both genders ${ }^{15}$. Several researchers have obtained the results that list a condom as the most common contraceptive. During time, the use of condoms has doubled and the number of those who do not use contraceptives or practice only coitus interruptus has been cut in half ${ }^{15}$. Despite the fact that only $5.8 \%$ of participants in this study expressed the need for some kind of professional help in dealing with their sexual life, it is important to point out that there are possible negative effects of sexual avoidance. It is possible that this type of behavior has a negative effect on sexual self-esteem because it disables people to experience the positive side of sexual activity ${ }^{16}$. When it comes to using contraceptives, students that reside in cities or towns use contraceptives despite the fact that they are in a serious long-term relationship. On the other hand, students coming from villages mostly use natural methods of birth control like coitus interruptus, avoiding fertile days and, considered as most effective, abstention. This could be because a city or a town has greater number of gynecologists and it is easier to access the information about contraceptives. In addition, larger communities like cities exhibit less stigmatization with respect to contraceptives, which is supported also by the results of a research done in Central America ${ }^{17}$. In relation to the availability of contraceptives, $50 \%$ of the participants stated that contraceptives were available. However, about $10 \%$ of the participants in each group stated that contraceptives were not available either because they lacked information and education on the use of contraceptives, or considered them to be too expensive. The majority of participants come from cities or towns where they can purchase contraceptives in variety of stores (pharmacies, supermarkets, coffee shops). Furthermore, it is possible that financial factor is less prominent in cities and towns. More than half of the participants, (71. 9\%), uses some kind of birth control. The most common contraceptives are condoms and oral contraceptives. The latter are considered to be the most efficient non-surgical birth control. Among women who use birth control pills, 1 in 200 women falls pregnant per year ${ }^{7}$. A research conducted among 341 high school students (70\% females and $21 \%$ males) in the Vocational Medical Schools in Zagreb has shown that two-thirds of the participants (64\%) uses a condom, whereas $7 \%$ of the participants use oral contraceptives, and $10 \%$ use other methods (abstention, diaphragm, avoiding fertile days, hormonal patches). The remaining participants listed coitus interruptus as the chosen birth control method ${ }^{18}$. A condom is a very reliable method of birth control if used properly. Less than five pregnancies per year occur with partners using a condom. Furthermore, if condoms are used correctly and in combination with spermicides, theoretical efficiency is greater and even very similar to the one of contraceptive pills. One of the most obvious advantages of a condom is the fact that it provides a sensation of security when it comes to sexually transmitted diseases (genital herpes and infections by human papilloma virus) and unwanted pregnancy ${ }^{6}$.

A research conducted at the University Rochester shows a growing trend among senior students in using oral contraceptives without a corresponding growth in the use of condoms ${ }^{19}$. Participants in this study, who did not use any contraceptive method, claimed that they were in a steady long-term relationship and were not afraid of sexually transmitted diseases or pregnancy. In a qualitative study conducted by the IPPF European Network in seven countries across Eastern Europe and Central Asia (Armenia, Bulgaria, Azerbaijan, Bosnia \& Herzegovina, Kazakhstan, Republic of Macedonia, and Serbia) where the level of modern contraceptive use is low, most of the students at the University of Osijek (Eastern Croatian Population) use some methods of birth control ${ }^{20}$.

It is known that exposure to risk factors during adolescence helps determine who will remain healthy later in life. Furthermore, we have come to recognize that major risks for cancer, diabetes, obesity, and cardiovascular disease commonly start or intensify during the teen years, and that most mental health disorders begin before the age of 25. There is currently no official service in Croatia where adolescents could find information and help regarding their sexual health. This poses a serious problem because it could have negative consequences on their health in general. Providing better standard of sexual information may promote improved levels of sexual self-esteem that, in turn, will positively influence sexual behavior, sexual functioning, sexual satisfaction, and sexual wellbeing. Promoting better sexual self-esteem among university students may have a positive impact on their sexual health rate ${ }^{21}$. To conclude, there are no significant differences in the age of first sexual activity by gender, year at university and residency. The biggest reason for not using contraception is involvement in a long-term relationship in which students do not feel fear of sexually transmitted 
diseases and pregnancy. In the absence of an official service in Croatia where adolescents could find information regarding their sexual health, students get most of their birth control information at school, although self-esteem and body image satisfaction are highly important for the development of their sexuality and health.

\section{Author Contributions}

D. Vučić, A. Lozić, M. Volarić performed the investigation and collected data. In addition, they were responsible for data validation and funding. Z. Bosnić and Lj. Trtica Majnarić were responsible for conceptualization, design of the study and formal analysis, and provided project administration. Lj. Trtica Majnarić supervised the study, Z. Bosnić wrote the manuscript. Ljiljana Trtica Majnarić reviewed and edited manuscript. All authors have read and agreed on the published version of the manuscript.

\section{Funding}

This study received no external funding.

\section{Conflicts of Interest}

The authors declare no conflict of interest. The funders had no role in the design of the study; in the collection, analyses, or interpretation of data; in the writing of the manuscript, or in the decision to publish the results.

\section{Ethical statement}

This study is a part of Antonio Lozic's thesis, approved by the Ethics Committee, Faculty of Medicine, Josip Juraj Strossmayer University of Osijek. CLASS:602-04/17-08/12, REG: 21589-61-07-17-73.

\section{R E F E R E N C E S}

1. MASTERS WH, JOHANSON VE, KOLODNY RC, Ljudska seksualnost, (Naklada Slap, Zagreb, 2006.) - 2. KAESTLE CE, HALPERN CT, MILLER WC, FORD CA, Am J Epidemiol, 16 (2005) 774. — 3. KAPPLER EM, Public Health Rep, 130 (2015) 196. — 4. ŚTULHOFER A, BUSKO V, LANDRIPET I, Arch Sex Behav, 39 (2010) 168. - 5. MAGNUSSON BM, MASHO SW, LAPANE KL, Sex Health, 8 (2011) 95. — 6. MASTER NT, CASEY E, BEADNELL B, MORRISO DM, HOPPE MJ, WELLS EA, J Sex Res, 52 (2015) 781. - 7. ŠIMUNIĆ V, et al.,. Ginekologija (Naklada Ljevak, Zagreb, 2001) - 8. CAMPBELL MJ, Statistics at Square Two (Blackwell Publishing, Oxford, 2006) - 9 . IVANKOVIĆ D. et al., Osnove statističke analize za medicinare, (Medicinski fakultet Sveučilišta u Zagrebu, Zagreb, 1988.) - 10. HOYT MA, CHASE LANDSALE PL, MCDADE TW, ADAM PK, The Journal of Adolescent Health 50 (2012) 66. - 11. SANTINELLI JS, BRENER ND, LOWRY R, BHATT A, ZABIN LS, Fam Plan Perspect, 30/6 (1998) 271. - 12. SIMBAR M, TEHRANI FR, HASHEMI Z, EMHJ, 11 (2005) 888.
- 13. DESIDERATO LL, CRAWFORD HJ, Journal of Youth and Adolescence, 24 (1995) 55. - 14. MAJNARIĆ TRTICA LJ, BOSNIC Z, GRDIC I, VOLARIC M, Journal of Psychology and Behavioral Science, 6 (2018) 60. - 15. ŠTULHOFER A, DOKMANOVIC M, AJDUKOVIC D, BOZICEVIC I, Pedagogijska istraživanja, 2 (2005) 327. - 16. KAESTLE CE, EVANS LM, Journal of American College Health, 1 (2017) 1. — 17. SAMANDARI G, SPEIZER IS, Int Perspect Sex Reprod Health, 36 (2010) 26. - 18. CROATIAN INSTITUTE OF PUBLIC HEALTH: Results of the Sexual Behavior Survey on Marking World AIDS Day 2016. Available on: http://spolnozdravlje.hr/clanak.php?id=12406. — 19. SIEGEL DM, KLEIN DI, ROGHMANN KJ, Journal of Adolescent Health, (1999) 25: 336-43. - 20. IPPF EUROPEAN NETWORK, Access to modern contraceptive choice in Eastern Europe and Central Asia, January 2016. https:// www.ippfen.org/resource/. — 21. HENSEL DJ, FORTENBERRY JD, Journal of Adolescent Health, 52/2 (2013) 219-22.

\section{Z. Bosnić}

Department of Internal Medicine, Family Medicine and the History of Medicine, Faculty of Medicine, Josip Juraj Strossmayer University of Osijek, Josipa Huttlera, 31000 Osijek, Croatia

e-mail: zbosnic191@gmail.com 


\section{OSOBITOSTI SPOLNOG ŽIVOTA I METODE KONTRACEPCIJE MEĐU STUDENTIMA SVEUČILIŠTA U OSIJEKU}

\section{S A Ž E T A K}

Cilj istraživanja je definirati osobitosti spolnog života i metode kontracepcije studenata Sveučilišta u Osijeku. U istraživanje su uključeni studenti Sveučilišta u Osijeku. Od metoda je korišten novoformirani strukturirani upitnik od 31 pitanja. U istraživanje je uključeno 549 studenata. U 54,3\% ispitanika prvi spolni odnos je bio između 16 . i 18. godine. Parovi u dugotrajnoj vezi bolje se snalaze po pitanju seksualne aktivnosti, dok su ispitanici u privremenim vezama značajnije više pod stresom studiranja. Kada je riječ o vrsti kontraceptiva, $71,9 \%$ učenika koristilo je neku od kontracepcijskih metoda, a najčešći je kondom (75,9 \%). Studenti koji ne koriste kontracepciju, navode da je za to najvažniji razlog, dugotrajna veza i sigurnost koja je vezana s njom za $50 \%$, dok mišljenje o sigurnosti prirodnih metoda ima 27,9 \% ispitanika. Ispitanici koji su nezadovoljni svojim izgledom, češće ne održavaju seksualne odnose ili ih održavaju rijetko, od onih koji su svojim izgledom zadovoljni. Nema značajnih razlika u početku spolnog odnosa u odnosu na spol, godine studija ili mjesto stanovanja. Najučestalija metoda kontracepcije je kondom zatim tablete. Kao najvažniji razlog nekorištenja kontracepcije, navedena je stalna partnerska veza, tako da ne postoji strah od spolnih bolesti i moguće trudnoće. 